\title{
Production of Copper and Cobalt Aluminate Spinels and Their Application As Supports for Inulinase Immobilization
}

\author{
Ederson Rossi Abaide ${ }^{a}$, Chayene Gonçalves Anchieta ${ }^{a}$, Vitória Segabinazzi Foletto ${ }^{b}$, Beatriz Reinehra,
} Lucielle Ferreira Nunes ${ }^{a}$, Raquel Cristine Kuhn ${ }^{a}$, Marcio Antonio Mazuttia, Edson Luiz Foletto ${ }^{a *}$

\author{
${ }^{a}$ Department of Chemical Engineering, Federal University of Santa Maria - UFSM, \\ Av. Roraima, 1000, Bairro Camobi, CEP 97105-900, Santa Maria, RS, Brazil \\ ${ }^{b}$ Departament of Industrial Pharmacy, Federal University of Santa Maria - UFSM, \\ Av. Roraima, 1000, Bairro Camobi, CEP 97105-900, Santa Maria, RS, Brazil
}

Received: July 20, 2015; Revised: September 5, 2015

\begin{abstract}
Copper and cobalt aluminates were obtained through the use of chitosan as template. In this synthesis route, chitosan is eliminated by heating, and a porous material is produced. These oxides were used as supports for inulinase immobilization by adsorption process. Physical properties of produced particles were analyzed by X-ray diffraction (XRD) and nitrogen adsorption-desorption isotherms. Both oxides presented particles containing mesoporous characteristics and high surface area, which is desirable for applications in enzyme immobilization processes. The results revealed that the copper and cobalt aluminates exhibit high inulinase immobilization efficiencies, which makes them promising supports for enzyme immobilization.
\end{abstract}

Keywords: $\mathrm{CuAl}_{2} \mathrm{O}_{4}, \mathrm{CoAl}_{2} \mathrm{O}_{4}$, synthesis, characterization, inulinase, immobilization

\section{Introduction}

Spinel structure oxides constitute one of the most interesting classes of advanced ceramic materials due their intrinsic physical and chemical properties. Among the spinel oxides, copper $\left(\mathrm{CuAl}_{2} \mathrm{O}_{4}\right)$ and cobalt $\left(\mathrm{CoAl}_{2} \mathrm{O}_{4}\right)$ aluminates possess interesting properties for technological application. Specifically, copper aluminate $\left(\mathrm{CuAl}_{2} \mathrm{O}_{4}\right)$ possesses important applications in various fields such as gases sensor ${ }^{1}$, catalyst in the oxidation reaction of benzyl alcohol ${ }^{2,3}$, methanol steam reforming ${ }^{4}$ and hydrogenolysis of glycerol ${ }^{5}$, thermoelectric properties $^{6}$, photocatalyst for degradating the pollutants in aqueous solution ${ }^{7-10}$, solar absorber ${ }^{11}$, oxygen carrier in chemical-looping combustion ${ }^{12}$ and optical and dielectric properties $^{2,13}$. Cobalt aluminate oxide $\left(\mathrm{CoAl}_{2} \mathrm{O}_{4}\right)$ has been employed in various fields such as ceramic pigment ${ }^{14,15}$, optical and magnetic properties ${ }^{16,17}$, catalysts in reactions such as soot combustion with $\mathrm{NO}_{\mathrm{x}} / \mathrm{O}_{2}{ }^{[18]}$, oxidation of $\mathrm{CO}^{[19]}$, carbon monoxide hydrogenation ${ }^{20}$, and reforming of methane ${ }^{21}$, and sensors for ga ${ }^{22}$, humidity ${ }^{23}$ and volatile organic compounds ${ }^{1,24}$.

The use of immobilized enzymes has been increased in the last years due the many fields application. In the immobilization process enzymes are trapped in a solid matrix, therefore, is possible the reuse and it will not be subjected to denaturation ${ }^{25}$. Several materials with different characteristics such as natural clay ${ }^{26}$, grafted alginate beads ${ }^{27}$, aminated non-porous silica nanoparticles ${ }^{28}$, chitin $^{29}$, alginate-chitosan beads $^{30}$, poly(EGDMA) cryogels ${ }^{31}$ and carbon nanotubes ${ }^{32}$ have been used as supports for inulinase immobilization by adsorption process. The immobilization process presents some

*e-mail: efoletto@gmail.com, foletto@smail.ufsm.br advantages compared with free enzyme, which are the easily removed of the products from immobilized enzymes and possibility the continuous mode of operation ${ }^{33}$. Immobilized inulinases have been used for many processes, especially for the sugar production through inulin hydrolysis, yielding fructose and fructooligosaccharides, which could be used as functional ingredient ${ }^{26}$. In this work a new application for copper and cobalt aluminate oxides was proposed, i.e., as support for inulinase immobilization.

Copper aluminate spinel $\left(\mathrm{CuAl}_{2} \mathrm{O}_{4}\right)$ has been prepared by several techniques such as microwave combustion method ${ }^{3}$, co-precipitation ${ }^{10}$, electrochemical process ${ }^{11}$, solvothermal ${ }^{20}$, microemulsion method ${ }^{34}$, sonochemical ${ }^{9,35}$, solid state reaction $^{4,36}$, sol-gel ${ }^{7,37}$, modified sol-gel ${ }^{2,38}$, sputtering ${ }^{13,39}$, Pechini method ${ }^{40}$ and metallic alkoxide ${ }^{41}$. Cobalt aluminate spinel $\left(\mathrm{CoAl}_{2} \mathrm{O}_{4}\right)$ has been prepared by reverse microemulsion process $^{16}$, sol-gel ${ }^{17}$, hydrothermal ${ }^{42,43}$, microwave combustion method $^{44}$, sonochemical ${ }^{45}$, via glycine chelated precursors ${ }^{46}$, via polyacrylamide gel method ${ }^{47}$, double decomposition reaction between solid $\mathrm{LiAlO}_{2}$ and molten $\mathrm{KCoCl}_{3}^{[48]}$, low temperature combustion ${ }^{49}$, complexation method ${ }^{50}$, reaction-sintering process ${ }^{51}$, polymeric precursors method ${ }^{52}$, polymeric-aerosol pyrolysis ${ }^{53}$, freeze-drying ${ }^{54}$, sol-gelhydrothermal method ${ }^{55}$, ultrasonic-assisted-hydrothermal method $^{56}$, polymerized complex technique ${ }^{57}$, chemical vapor deposition ${ }^{58}$, and via supercritical water conditions ${ }^{59}$. In this work, both copper and cobalt aluminates were prepared by route using chitosan as template. This technique has as advantages obtain a material with high porosity and surface $\operatorname{area}^{60}$. These characteristics are important for enzymes 
immobilization purposes. Although some aluminum-based spinels have been prepared using chitosan as template ${ }^{61,62}$, copper and cobalt aluminates have not yet been prepared by this route.

Hence, in the present study, copper and cobalt aluminates were prepared by the route using chitosan as template. The spinel oxides were prepared at two different temperatures, and their physical properties were determined. Both oxides were evaluated as supports for inulinase immobilization.

\section{Experimental}

\subsection{Synthesis of oxides}

Synthesis procedure of copper and cobalt aluminates was based in a previous work $^{62}$, however ultrasonic irradiation was here employed in order to aid the mixing process. $\mathrm{CuAl}_{2} \mathrm{O}_{4}$ and $\mathrm{CoAl}_{2} \mathrm{O}_{4}$ powders were prepared from aluminum nitrate $\left(\mathrm{Al}\left(\mathrm{NO}_{3}\right)_{3} \cdot 9 \mathrm{H}_{2} \mathrm{O}\right)$, cobalt chloride $\left(\mathrm{CoCl}_{2} \cdot 6 \mathrm{H}_{2} \mathrm{O}\right)$, copper nitrate $\left(\mathrm{Cu}\left(\mathrm{NO}_{3}\right)_{2} \cdot 3 \mathrm{H}_{2} \mathrm{O}\right)$ and commercial chitosan $\left(\mathrm{C}_{6} \mathrm{H}_{11} \mathrm{O}_{4} \mathrm{~N}\right)_{\mathrm{n}}$ (Purifama, Brazil). All the chemicals (with analytical grade) were used as received. Stoichiometric amounts of metal nitrates (molar ratio $\mathrm{Cu}: \mathrm{Al}=1: 2$ and $\mathrm{Co}: \mathrm{Al}=1: 2$ ) were used for preparing $\mathrm{CuAl}_{2} \mathrm{O}_{4}$ and $\mathrm{CoAl}_{2} \mathrm{O}_{4}$ powders. For preparing the copper aluminate $\left(\mathrm{CuAl}_{2} \mathrm{O}_{4}\right)$, aqueous solutions of aluminum nitrate (15 g in $30 \mathrm{~mL}$ distilled water) and copper nitrate ( $4.82 \mathrm{~g}$ in $8 \mathrm{~mL}$ distilled water) were added into an acetic acid aqueous solution $(5 \% \mathrm{v} / \mathrm{v})(80 \mathrm{~mL})$ containing $2.5 \mathrm{~g}$ of chitosan previously dissolved, under magnetic stirring. The mixture was ultrasonicated at $30^{\circ} \mathrm{C}$ for $30 \mathrm{~min}$ in an ultrasonic bath (Unique Inc., model USC 1800A, $35 \mathrm{kHz}$ Brazil). After that, the resulting solution was slowly added to an ammonia aqueous solution $(50 \% \mathrm{v} / \mathrm{v}, 200 \mathrm{~mL})$ under magnetic stirring. The formed precipitates were separated from the solution and further dried at ambient temperature for $48 \mathrm{~h}$. Then, the solids were calcined in air at $650{ }^{\circ} \mathrm{C}$ and $900{ }^{\circ} \mathrm{C}$ for $4 \mathrm{~h}$, using a conventional muffle-furnace. Cobalt aluminate powders were prepared by same procedure previously described, but the amounts used for the synthesis were $15 \mathrm{~g}$ of aluminum nitrate and $4.76 \mathrm{~g}$ of cobalt chloride.

\subsection{Characterization techniques of oxides}

The phase identification of the samples was carried out by XRD (Rigaku Miniflex 300 diffractometer) using $\mathrm{Cu} K \alpha$ radiation at $30 \mathrm{kV}$ and $10 \mathrm{~mA}$, with a step size (2 $\theta)$ of $0.03^{\circ}$ and a count time of $0.9 \mathrm{~s}$ per step. The average crystallite size of each sample was determined through the Scherrer equation ${ }^{63}$ (silicon powder was used as a standard reference material): $D=K \cdot \lambda /\left(\mathrm{h}_{1 / 2} \cdot \cos \theta\right)$, where $D$ is the average crystallite size, $K$ the Scherrer constant (0.9), $\lambda$ the wavelength of incident X-rays $(0.1541 \mathrm{~nm}), h_{1 / 2}$ the peak width at half height and $\theta$ corresponds to the peak position $\left(2 \theta=36.88^{\circ}\right.$, lattice plane of $\{311\}$ for $\mathrm{CuAl}_{2} \mathrm{O}_{4}$ and $36.74^{\circ}$, lattice plane of $\{311\}$ for $\left.\mathrm{CoAl}_{2} \mathrm{O}_{4}\right)$. $\mathrm{N}_{2}$ adsorption-desorption isotherms measurements were carried out at $77 \mathrm{~K}$ using an ASAP 2020 apparatus. Before analysis the samples were degassed at $200{ }^{\circ} \mathrm{C}$ under vacuum. Silica-alumina pellets (Part No. 004-16821-00) were used as a reference material to test instrument performance.

\subsection{Enzyme immobilization and activity essays}

Adsorption experiments were carried out to investigate the inulinase immobilization from aqueous solution. Commercial inulinase was obtained from Aspergillus niger (fructozyme, exo-inulinase EC 3.2.1.80 and endo-inulinase EC 3.2.1.7) and it was purchased from Sigma-Aldrich (São Paulo, Brazil). The temperature was fixed at $30^{\circ} \mathrm{C}$ and the inulinase adsorption was performed using a batch technique. Typically, $0.025 \mathrm{~g}$ of oxide was placed in glass flasks containing different inulinase concentrations in a sodium acetate buffer $(\mathrm{pH}$ 4.8) solution. The effects of enzyme concentration ( 0.5 ; 1.0 and $1.5 \% \mathrm{v} / \mathrm{v})$ and adsorbent:adsorbate ratio $(1: 300$ 1:500) on the adsorption were evaluated. The solution was maintained under agitation at $150 \mathrm{rpm}$, and then an aliquot of the aqueous solution was collected after reaching the adsorption equilibrium time (90 $\mathrm{min}$ ), and then filtered through the polyvinylidene difluoride (PVDF) membrane $(0.22 \mu \mathrm{m})$ before analysis. For the enzyme activity essays, an aliquot of enzyme $(0.5 \mathrm{~mL})$ was incubated with sucrose solution $(4.5 \mathrm{~mL}, 2 \% \mathrm{w} / \mathrm{v})$ in sodium acetate buffer $(0.1 \mathrm{M}$, $\mathrm{pH} 4.8)$ at $50{ }^{\circ} \mathrm{C}$. Released reducing sugars were measured by the 3.5 -dinitrosalicylic acid method ${ }^{64}$. A separate blank was set up for each sample to correct the non-enzymatic release of sugars. One unit of inulinase activity was defined as the amount of enzyme necessary to hydrolyze $1 \mu \mathrm{mol}$ of sucrose per minute under the mentioned conditions (sucrose as a substrate). The immobilization efficiency was expressed in terms of inulinase loading capacity $\left(Q_{T}: \mathrm{U} \mathrm{g}^{-1}\right)$ through the Equation 1.

$\mathrm{Q}_{\mathrm{t}}=\frac{\left(\mathrm{A}_{0}-\mathrm{A}_{\mathrm{t}}\right) \mathrm{V}}{\mathrm{m}}$

where $A_{O}$ and $A_{T}\left(\mathrm{U} \mathrm{L}^{-1}\right)$ are the inulinase activities at $t=0$ and time $t$, respectively; $V(\mathrm{~L})$ is the volume of solution, and $m(\mathrm{~g})$ is the mass of support.

All the immobilization experiments were carried out in duplicate and only the mean values were reported. The maximum deviation observed was about $\pm 6.0 \%$.

\section{Results and Discussion}

\subsection{Characterization of oxides}

The XRD patterns of the copper and cobalt aluminates prepared at different temperatures are shown in Figure 1 (profiles a and b, respectively). Copper aluminate samples showed diffraction peaks at $2 \theta$ values of $31.20^{\circ}, 36.88^{\circ}$, $44.85^{\circ}, 55.73^{\circ}, 59.42^{\circ}$ and $65.40^{\circ}$ corresponding to the [220], [311], [400], [422], [511] and [440] diffraction planes, respectively. Cobalt aluminate samples showed diffraction peaks at $2 \theta$ values of $31.19^{\circ}, 36.74^{\circ}, 44.69,55.49^{\circ}, 59.19^{\circ}$ and $65.4^{\circ}$ corresponding to the [220], [311], [400], [422], [511] and [440] planes, respectively. These planes are associated with the spinel types $\mathrm{CuAl}_{2} \mathrm{O}_{4}$ and $\mathrm{CoAl}_{2} \mathrm{O}_{4}$ with cubic structures in agreement with the Joint Committee on Powder Diffraction Standards (JCPDS) cards no. 33-0448 and no. 44-0160, respectively. On the basis of the Scherrer equation, the crystallite size was calculated to be ca. 7.5 for both $\mathrm{CuAl}_{2} \mathrm{O}_{4}$ samples, and ca. 6.0 and $8.0 \mathrm{~nm}$ for the $\mathrm{CoAl}_{2} \mathrm{O}_{4}$ samples prepared at 650 and $900^{\circ} \mathrm{C}$, respectively.

Figure 2 shows the adsorption-desorption isotherms of $\mathrm{N}_{2}$ of cobalt and copper oxides prepared at 650 and $900{ }^{\circ} \mathrm{C}$. 
All samples present type-IV isotherms (Figure 2a), in accordance with the International Union of Pure and Applied Chemistry (IUPAC) classification ${ }^{65}$. This adsorption behavior is characteristics of mesoporous structure. The desorption branches present H1-like hysteresis loops at high relative pressures, indicative of the presence of mesoporosity. The corresponding pore size distribution curves (Figure 2b) were measured from the adsorption branches according to the Barrett-Joyner-Halenda (BJH) method. All samples display a similar unimodal distribution, with peaks centered in the mesoporous region (between 20 and $500 \AA$ ). These features are of great importance for immobilization purposes because it allows for a greater accessibility of enzymes molecules to the support. Surface physical parameters of all samples are shown in Table 1. It can be observed that specific surface area decreases with increasing calcination temperature. Thus samples prepared at $650{ }^{\circ} \mathrm{C}$ present higher surface area. This can occur due to sintering of material when it is treated at higher temperatures, resulting in reducing the void spaces and consequently, its surface area ${ }^{66}$.

For comparison purposes, surface area values of $\mathrm{CuAl}_{2} \mathrm{O}_{4}$ and $\mathrm{CoAl}_{2} \mathrm{O}_{4}$ powders found in literature are shown in Table 2. From Table 2, it can be seen that each method results in materials with different surface areas. Therefore, the preparation route strongly affects their physical properties. The results revealed that the route presented in this work

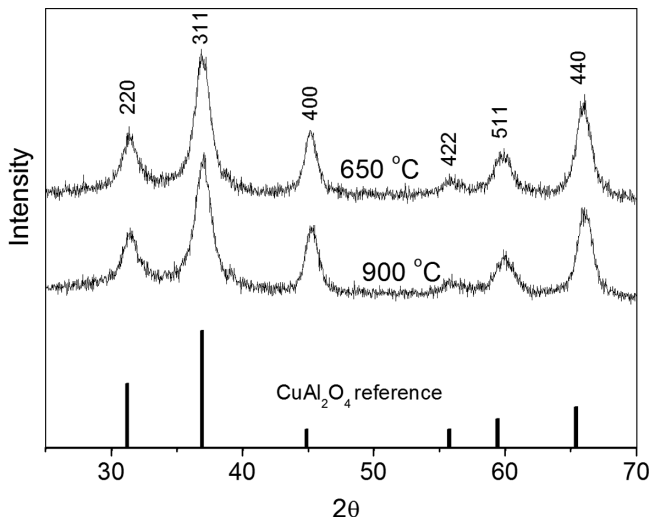

(a)

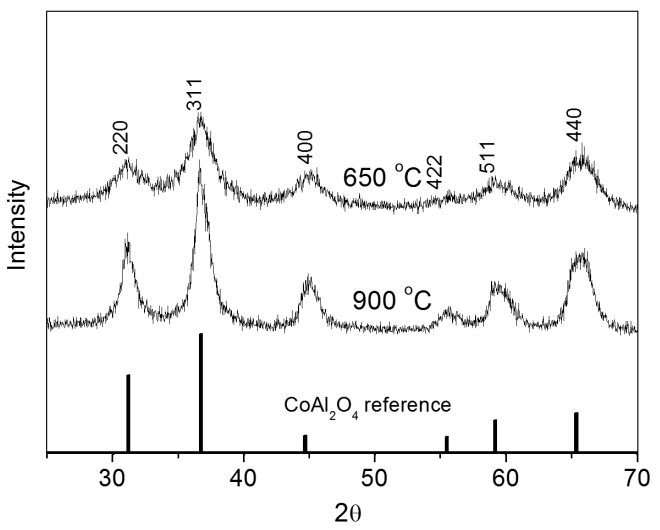

(b)

Figure 1. XRD patterns of (a) copper and (b) cobalt aluminates prepared at 650 and $900{ }^{\circ} \mathrm{C}$. Inset at figure (a): $\mathrm{CuAl}_{2} \mathrm{O}_{4}$ reference according to JCPDS card no. 33-0448, and inset at figure (b): $\mathrm{CoAl}_{2} \mathrm{O}_{4}$ reference according to JCPDS card no. 44-0160. generates materials with a high surface area. So preparation of single phase spinel with porous structure and high surface area makes this method technically easier, simpler and low cost because it does not need sophisticated procedures and requires inexpensive precursors.

Table 1. Surface physical characteristics of oxide samples prepared at different conditions.

\begin{tabular}{|c|c|c|c|c|}
\hline Properties & $\begin{array}{l}\mathrm{CuAl}_{2} \mathrm{O}_{4} / \\
650^{\circ} \mathrm{C}\end{array}$ & $\begin{array}{c}\mathrm{CuAl}_{2} \mathrm{O}_{4} / \\
900^{\circ} \mathrm{C}\end{array}$ & $\begin{array}{l}\mathrm{CoAl}_{2} \mathrm{O}_{4} / \\
650^{\circ} \mathrm{C}\end{array}$ & $\begin{array}{c}\mathrm{CoAl}_{2} \mathrm{O}_{4} / \\
900{ }^{\circ} \mathrm{C}\end{array}$ \\
\hline $\begin{array}{l}\text { BET surface } \\
\text { area }\left(\mathrm{m}^{2} \mathrm{~g}^{-1}\right)\end{array}$ & 72.79 & 23.60 & 192.27 & 116.72 \\
\hline $\begin{array}{l}\text { Micropore } \\
\text { surface area } \\
\left(\mathrm{m}^{2} \mathrm{~g}^{-1}\right)\end{array}$ & 10.26 & 5.57 & 3.05 & 10.02 \\
\hline $\begin{array}{c}\text { External } \\
\text { surface area } \\
\left(\mathrm{m}^{2} \mathrm{~g}^{-1}\right)\end{array}$ & 62.53 & 18.03 & 189.22 & 106.70 \\
\hline $\begin{array}{l}\text { Langmuir } \\
\text { surface area } \\
\left(\mathrm{m}^{2} \mathrm{~g}^{-1}\right)\end{array}$ & 99.77 & 30.16 & 266.86 & 161.31 \\
\hline $\begin{array}{l}\text { Total pore } \\
\text { volume } \\
\left(\mathrm{cm}^{3} \mathrm{~g}^{-1}\right)\end{array}$ & 0.295 & 0.218 & 0.369 & 0.336 \\
\hline $\begin{array}{l}\text { Micropore } \\
\text { volume } \\
\left(\mathrm{cm}^{3} \mathrm{~g}^{-1}\right)\end{array}$ & 0.0042 & 0.0232 & 0.0004 & 0.0036 \\
\hline $\begin{array}{l}\text { Mesopore } \\
\text { volume } \\
\left(\mathrm{cm}^{3} \mathrm{~g}^{-1}\right)\end{array}$ & 0.290 & 0.194 & 0.369 & 0.332 \\
\hline $\begin{array}{l}\text { Average } \\
\text { pore size } \\
(\AA)\end{array}$ & 162.13 & 180.4 & 96.76 & 115.14 \\
\hline
\end{tabular}

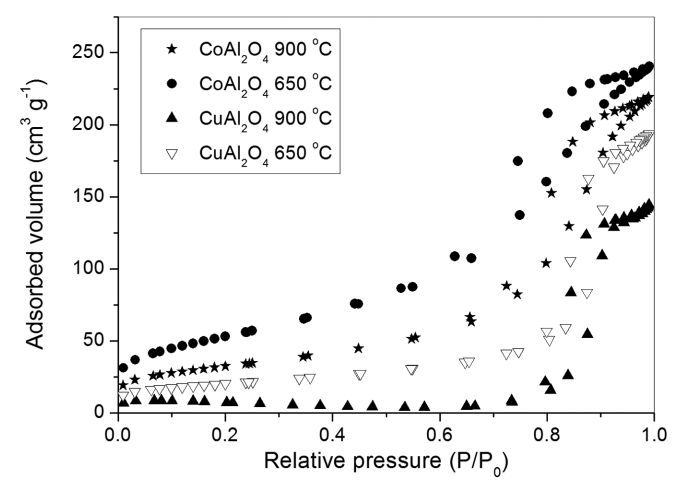

(a)

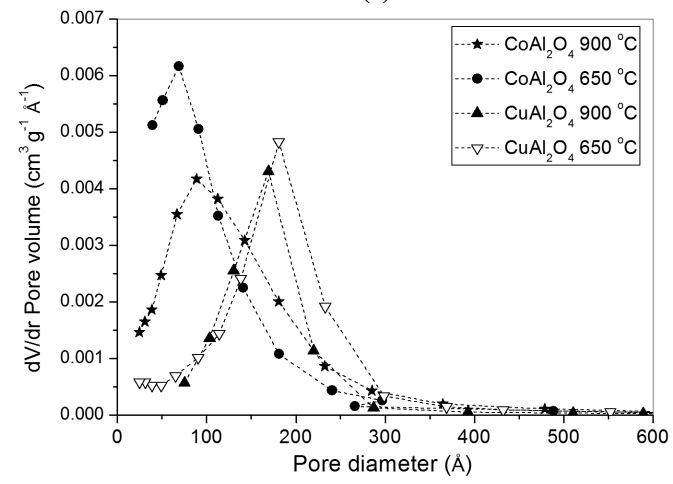

(b)

Figure 2. (a) $\mathrm{N}_{2}$ adsorption-desoption isotherms and (b) Barret-JoynerHalenda $(\mathrm{BJH})$ pore size distributions plots of different samples. 
Table 2. Comparing the surface area values of different synthesis methods found in the literature.

\begin{tabular}{|c|c|c|c|}
\hline \multicolumn{2}{|c|}{$\mathrm{CoAl}_{2} \mathrm{O}_{4}$} & \multicolumn{2}{|l|}{$\mathrm{CuAl}_{2} \mathrm{O}_{4}$} \\
\hline Method & $\begin{array}{l}\text { Surface area } \\
\qquad\left(\mathrm{m}^{2} \mathrm{~g}^{-1}\right)\end{array}$ & Method & $\begin{array}{l}\text { Surface area } \\
\qquad\left(\mathbf{m}^{2} \mathbf{g}^{-1}\right)\end{array}$ \\
\hline Microwave assisted glycothermal ${ }^{18}$ & 181 & Sol-gel ${ }^{1}$ & 10 \\
\hline Hydrothermal $^{42}$ & 29 & Sol-gel ${ }^{2}$ & 10 \\
\hline Sonochemical ${ }^{45}$ & 75 & Modified sol-gel ${ }^{2}$ & 41 \\
\hline Low temperature combustion ${ }^{49}$ & 77 & Solid-state reaction ${ }^{4}$ & 13 \\
\hline Autoignition $^{67}$ & 16 & Sonochemical $^{9}$ & 110 \\
\hline Colloidal sol-gel ${ }^{68}$ & 156 & Dry soaking ${ }^{74}$ & 30 \\
\hline Combustion $^{69}$ & 188 & Microwave combustion ${ }^{75}$ & 87 \\
\hline Microwave $^{70}$ & 94 & Conventional combustion ${ }^{75}$ & 44 \\
\hline Coprecipitation $^{71}$ & 169 & Mixed chelates thermolysis ${ }^{76}$ & 86 \\
\hline Solution-based combustion ${ }^{72}$ & 53 & Soft chemical approach ${ }^{77}$ & 5 \\
\hline Malonate $^{73}$ & 23 & Copper-laden sludge thermally treated ${ }^{78}$ & 2 \\
\hline
\end{tabular}

Table 3. Inulinase loading capacity $\left(Q_{T}\right)$ of $\mathrm{CuAl}_{2} \mathrm{O}_{4}$ and $\mathrm{CoAl}_{2} \mathrm{O}_{4}$ samples.

\begin{tabular}{ccccc}
\hline Assays & $\begin{array}{c}\text { Enzyme concentration } \\
(\%, \mathbf{v} / \mathbf{v})\end{array}$ & Adsorbent:adsorbate ratio & $\begin{array}{c}\mathbf{C u A l} \mathbf{O}_{4} \\
\left(\boldsymbol{Q}_{T}: \mathbf{U}^{-1}\right)\end{array}$ & $\begin{array}{c}\mathbf{C o A l} \mathbf{O}_{4} \\
\left(\boldsymbol{Q}_{T}: \mathbf{U}^{-1}\right)\end{array}$ \\
\hline 1 & 0.5 & $1: 300$ & 6,642 & 1,461 \\
2 & 1.5 & $1: 300$ & 7,337 & 3,772 \\
3 & 0.5 & $1: 500$ & 8,510 & 1,312 \\
4 & 1.5 & $1: 500$ & 5,623 & 8,343 \\
5 & 1.0 & $1: 400$ & 1,329 & 4,706 \\
\hline
\end{tabular}

As cobalt- and copper-based oxides are colored materials, so this detail was evidenced from visual examination (Figure 3), whose images were obtained by a commercial digital camera (Nikon Coolpix). The powders were compacted on a glass sample holder. These results aimed provide additional information regarding the physical characteristics of produced materials, i.e., their intrinsic color. The samples containing cobalt exhibit a bright blue color whereas samples containing copper are greenish/ yellowish. Cobalt aluminate has been used as blue ceramic pigment ${ }^{14,15}$, whereas copper-based oxides as green/yellow/turquoise pigments ${ }^{79-81}$.

\subsection{Enzyme immobilization}

The enzyme immobilization assays were performed using only the copper aluminate and cobalt aluminate samples at $650{ }^{\circ} \mathrm{C}$, because in this temperature was obtained the highest surface area (see Table 1). Table 3 shows the results for inulinase loading capacity using copper and cobalt aluminates. Copper aluminate sample presented a loading capacity of $8,510 \mathrm{U} \mathrm{g}^{-1}$ using an inulinase concentration of $0.5 \%(\mathrm{v} / \mathrm{v})$ and 1:500 of adsorbent:adsorbate ratio, whereas cobalt aluminate sample presented similar loading capacity $\left(8,343 \mathrm{U} \mathrm{g}^{-1}\right)$ under the same adsorbent:adsorbate ratio (1:500), but using an inulinase concentration of $1.5 \%(\mathrm{v} / \mathrm{v})$. The results showed that the cobalt aluminate presents more capacity for inulinase adsorption, which could be explained by the surface area value, being higher when compared to the cupper aluminate. Table 4 shows the inulinase loading capacity of different supports found in literature. According

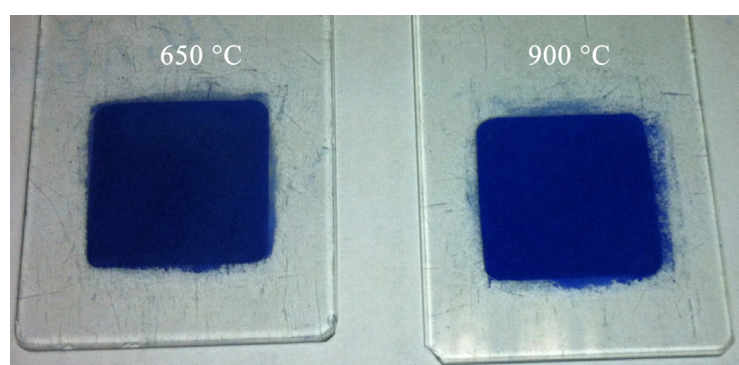

(a)

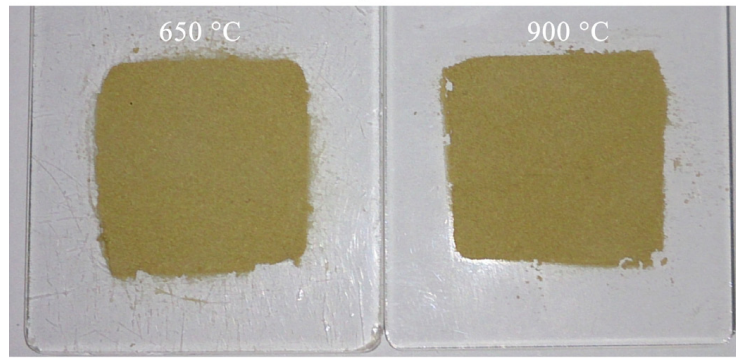

(b)

Figure 3. Images of (a) $\mathrm{CoAl}_{2} \mathrm{O}_{4}$ and (b) $\mathrm{CuAl}_{2} \mathrm{O}_{4}$ samples obtained at different temperatures.

to the results founded it is possible to observe that both aluminates presented a satisfactory inulinase loading capacity. This result could be explained by the high surface area values of both samples prepared in this work. 
Table 4. Inulinase loading capacity $\left(Q_{T}\right)$ of different supports found in literature.

\begin{tabular}{lc}
\hline \multicolumn{1}{c}{ Material } & $\boldsymbol{Q}_{T}\left(\mathbf{U ~ g ~}^{-1}\right)$ \\
\hline Grafted alginate beads $^{27}$ & 530 \\
Chitin $^{29}$ & 291 \\
Alginate-chitosan beads $^{30}$ & 668 \\
Carbon nanotubes $^{32}$ & 51,047 \\
Aminated non-porous silica $^{82}$ & 43 \\
Anion-exchange resins $^{83}$ & 11,000 \\
${\text { Poly-D-lysine coated } \mathrm{CaCO}_{3}}$ micro-particles $^{84}$ & 32 \\
\hline
\end{tabular}

\section{References}

1. Vijaya JJ, Kennedy LJ, Sekaran G, Bayhan M and William MA. Preparation and VOC gas sensing properties of Sr(II)-added copper aluminate spinel composites. Sensors and Actuators. B, Chemical. 2008; 134(2):604-612. http://dx.doi.org/10.1016/j. snb.2008.06.012.

2. Kumar RT, Suresh P, Selvam NCS, Kennedy LJ and Vijaya JJ. Comparative study of nano copper aluminate spinel prepared by sol-gel and modified sol-gel techniques: structural, electrical, optical and catalytic studies. Journal of Alloys and Compounds. 2012; 522(5):39-45. http://dx.doi.org/10.1016/j. jallcom.2012.01.064.

3. Ragupathi C, Vijaya JJ, Kennedy LJ and Bououdina M. Nanostructured copper aluminate spinels: synthesis, structural, optical, magnetic, and catalytic properties. Materials Science in Semiconductor Processing. 2014; 24:46-156. http://dx.doi. org/10.1016/j.mssp.2014.03.026.

4. Huang YH, Wang SF, Tsai AP and Kameoka S. Reduction behavior sand catalytic properties form ethanol steam reforming of Cu-based spinel compounds $\mathrm{CuX}_{2} \mathrm{O}_{4}(\mathrm{X}=\mathrm{Fe}, \mathrm{Mn}, \mathrm{Al}, \mathrm{La})$. Ceramics International. 2014; 40(3):4541-4551. http://dx.doi. org/10.1016/j.ceramint.2013.08.130.

5. Kwak BK, Park DS, Yun YS and Yi J. Preparation and characterization of nanocrystalline $\mathrm{CuAl}_{2} \mathrm{O}_{4}$ spinel catalysts by sol-gel method for the hydrogenolysis of glycerol. Catalysis Communications. 2012; 24:90-95. http://dx.doi.org/10.1016/j. catcom.2012.03.029.

6. Yanagiya S, Van Nong N, Xu J and Pryds N. The effect of (Ag, $\mathrm{Ni}, \mathrm{Zn}$ )-addition on the thermoelectric properties of copper aluminate. Materials (Basel). 2010; 3(1):318-328. http://dx.doi. org/10.3390/ma3010318.

7. Yanyan J, Jinggang L, Xiaotao S, Guiling N, Chengyu W and Xiumei G. $\mathrm{CuAl}_{2} \mathrm{O}_{4}$ powder synthesis by sol-gel method and its photodegradation property under visible light irradiation. Journal of Sol-Gel Science and Technology. 2007; 42(1):41-45. http://dx.doi.org/10.1007/s10971-006-1525-3.

8. Ding D, Long M, Cai W, Wu Y, Wu D and Chen C. In-situ synthesis of photocatalytic $\mathrm{CuAl}_{2} \mathrm{O}_{4}-\mathrm{Cu}$ hybrid nanorod arrays. Chemical Communications. 2009; 24(24):3588-3590. http:// dx.doi.org/10.1039/b903865e.

9. Lv W, Liu B, Qiu Q, Wang F, Luo Z, Zhang P, et al. Synthesis, characterization and photocatalytic properties of spinel $\mathrm{CuAl}_{2} \mathrm{O}_{4}$ nanoparticles by a sonochemical method. Journal of Alloys and Compounds. 2009; 479(1-2):480-483. http://dx.doi.org/10.1016/j. jallcom.2008.12.111.

\section{Conclusions}

Copper and cobalt aluminates were successfully synthesized using chitosan as template. The powders produced presented high surface area and mesoporous structure. These features are of great importance for immobilization purposes because it allows a greater accessibility of enzyme molecules to the support. Both aluminates presented a satisfactory loading capacity for inulinase immobilization. Therefore, these results revealed that copper and cobalt aluminates can be used as alternative supports for enzymes immobilization.

\section{Acknowledgements}

The authors gratefully acknowledge the financial support of the Brazilian research funding institutions $\mathrm{CNPq}$ and CAPES.

10. Gherbi R, Nasrallah N, Amrane A, Maachi R and Trari M. Photocatalytic reduction of $\mathrm{Cr}(\mathrm{VI})$ on the new hetero-system $\mathrm{CuAl}_{2} \mathrm{O}_{4} / \mathrm{TiO}_{2}$. Journal of Hazardous Materials. 2011; 186(23):1124-1130. http://dx.doi.org/10.1016/j.jhazmat.2010.11.105.

11. Ding D, Cai W, Long M, Wu H and Wu Y. Optical, structural and thermal characteristics of $\mathrm{Cu}-\mathrm{CuAl}_{2} \mathrm{O}_{4}$ hybrids deposited in anodic aluminum oxide as selective solar absorber. Solar Energy Materials and Solar Cells. 2010; 94(10):1578-1581. http://dx.doi.org/10.1016/j.solmat.2010.04.075.

12. Arjmand M, Azad AM, Leion H, Mattisson T and Lyngfelt A. Evaluation of $\mathrm{CuAl}_{2} \mathrm{O}_{4}$ as an oxygen carrier in chemical-looping combustion. Industrial \& Engineering Chemistry Research. 2012; 51(43):13924-13934. http://dx.doi.org/10.1021/ie300427w.

13. Leu LC, Norton DP, Jellison GE Jr, Selvamanickam V and Xiong X. Optical and dielectric properties of $\mathrm{CuAl}_{2} \mathrm{O}_{4}$ films synthesized by solid-phase epitaxy. Thin Solid Films. 2007; 515(17):6938-6942. http://dx.doi.org/10.1016/j.tsf.2007.02.012.

14. Gaudon M, Robertson LC, Lataste E, Duttine M, Ménétrier M and Demourgues A. Cobalt and nickel aluminate spinels: blue and cyan pigments. Ceramics International. 2014; 40(4):52015207. http://dx.doi.org/10.1016/j.ceramint.2013.10.081.

15. Torkian L and Daghighi M. Effects of $\beta$-alanine on morphology and optical properties of $\mathrm{CoAl}_{2} \mathrm{O}_{4}$ nanopowders as a blue pigment. Advanced Powder Technology. 2014; 25(2):739-744. http://dx.doi.org/10.1016/j.apt.2013.11.003.

16. Chandradass J, Balasubramanian $\mathrm{M}$ and Kim KH. Size effect on the magnetic property of $\mathrm{CoAl}_{2} \mathrm{O}_{4}$ nanopowders prepared by reverse micelle processing. Journal of Alloys and Compounds. 2010; 506(1):395-399. http://dx.doi.org/10.1016/j. jallcom.2010.07.014.

17. Duan X, Pan M, Yu F and Yuan D. Synthesis, structure and optical properties of $\mathrm{CoAl}_{2} \mathrm{O}_{4}$ spinel nanocrystals. Journal of Alloys and Compounds. 2011; 509(3):1079-1083. http://dx.doi. org/10.1016/j.jallcom.2010.09.199.

18. Zawadzki M, Walerczyk W, López-Suárez FE, Illán-Gómez MJ and Bueno-López A. $\mathrm{CoAl}_{2} \mathrm{O}_{4}$ spinel catalyst for soot combustion with $\mathrm{NO}_{x} / \mathrm{O}_{2}$. Catalysis Communications. 2011; 12(13):12381241. http://dx.doi.org/10.1016/j.catcom.2011.04.021.

19. Thormählen P, Fridell E, Cruise N, Skoglundh M and Palmqvist A. The influence of $\mathrm{CO}_{2}, \mathrm{C}_{3} \mathrm{H}_{6}, \mathrm{NO}, \mathrm{H}_{2}, \mathrm{H}_{2} \mathrm{O}$ or $\mathrm{SO}_{2}$ on the low-temperature oxidation of $\mathrm{CO}$ on a cobalt-aluminate spinel catalyst $\left(\mathrm{Co}_{1.66} \mathrm{Al}_{1.34} \mathrm{O}_{4}\right)$. Applied Catalysis B: Environmental. 2001; 31(1):1-12. http://dx.doi.org/10.1016/S0926-3373(00)00267-8.

20. Rojanapipatkul S and Jongsomjit B. Synthesis of cobalt on cobalt-aluminate via solvothermal method and its catalytic properties for carbon monoxide, hydrogenation. Catalysis 
Communications. 2008; 10(2):232-236. http://dx.doi.org/10.1016/j. catcom.2008.08.026.

21. Mo L, Fei J, Huang $C$ and Zheng X. Reforming of methane with oxygen and carbon dioxide to produce syngas over a novel $\mathrm{Pt} / \mathrm{CoAl} \mathrm{O}_{4} / \mathrm{Al}_{2} \mathrm{O}_{3}$ catalyst. Journal of Molecular Catalysis A Chemical. 2003; 193(1-2):177-184. http://dx.doi.org/10.1016/ S1381-1169(02)00453-3.

22. Michel CR. $\mathrm{CO}$ and $\mathrm{CO} 2$ gas sensing properties of mesoporous CoA12O4. Sensors and Actuators. B, Chemical. 2010; 147(2):635641. http://dx.doi.org/10.1016/j.snb.2010.04.013.

23. Vijaya JJ, Kennedy LJ, Sekaran G, Jeyaraj B and Nagaraja $\mathrm{KS}$. Effect of Sraddition on the humidity sensing properties of $\mathrm{CoAl}_{2} \mathrm{O}_{4}$ composites. Sensors and Actuators. B, Chemical. 2007; 123(1):211-217. http://dx.doi.org/10.1016/j.snb.2006.08.011.

24. Vijaya JJ, Kennedy LJ, Sekaran G, Meenakshisundaram A, Kumar RT, Amalthi P, et al. Alcohol sensing properties of solgel prepared $\mathrm{Sr}(\mathrm{II})$-added cobalt aluminate spinel composites. Sensors and Actuators. B, Chemical. 2008; 129(2):741-749. http://dx.doi.org/10.1016/j.snb.2007.09.031.

25. Daoud FB, Kaddour S and Sadoun T. Adsorption of cellulose Aspergillus niger on a commercial activated carbon: kinetic and equilibrium studies. Colloids and Surfaces. B, Biointerfaces. 2010; 75(1):93-99. http://dx.doi.org/10.1016/j.colsurfb.2009.08.019.

26. Coghetto CC, Scherer RP, Silva MF, Golunski S, Pergher SBC, Oliveira D, et al. Natural montmorillonite as support for the immobilization of inulinase from Kluyveromyces marxianus NRRL Y-7571. Biocatalysis and Agricultural Biotechnology. 2012; 1(4):284-289. http://dx.doi.org/10.1016/j.bcab.2012.06.005.

27. Danial EN, Elnashar MMM and Awad GEA. Immobilized inulinase on grafted alginate beads prepared by the one-step and the two-steps methods. Industrial \& Engineering Chemistry Research. 2010; 49(7):3120-3125. http://dx.doi.org/10.1021/ ie100011z.

28. Karimi M, Chaudhury I, Jianjun C, Safari M, Sadeghi R, Habibi-Rezaei M, et al. Immobilization of endo-inulinase on non-porous amino functionalized silica nanoparticles. Journal of Molecular Catalysis. B, Enzymatic. 2014; 104:48-55. http:// dx.doi.org/10.1016/j.molcatb.2014.01.025.

29. Nguyen QD, Rezessy-Szabó JM, Czukor B and Hoschke Á. Continuous production of oligofructose syrup from Jerusalem artichoke juice by immobilized endo-inulinase. Process Biochemistry. 2011; 46(1):298-303. http://dx.doi.org/10.1016/j. procbio.2010.08.028.

30. Missau J, Scheid AJ, Foletto EL, Jahn SL, Mazutti MA and Kuhn RC. Immobilization of commercial inulinase on alginatechitosan beads. Sustainable Chemical Processes. 2014; 2(1):13. http://dx.doi.org/10.1186/2043-7129-2-13.

31. Altunbaş C, Uygun M, Uygun DA, Akgöl S and Denizli A. Immobilization of inulinase on concanavalin A-attached super macroporous cryogel for production of high-fructose syrup. Applied Biochemistry and Biotechnology. 2013; 170(8):19091921. http://dx.doi.org/10.1007/s12010-013-0322-z.

32. Garlet TB, Weber CT, Klaic R, Foletto EL, Jahn SL, Mazutti $\mathrm{MA}$, et al. Carbon nanotubes as supports for inulinase immobilization. Molecules (Basel, Switzerland). 2014; 19(9):14615-14624. http://dx.doi.org/10.3390/molecules190914615.

33. Fernandes P, Marques MPC, Carvalho F and Cabral JMS. A simple method for biocatalyst immobilization using PVAbased hydrogel particles. Journal of Chemical Technology and Biotechnology (Oxford, Oxfordshire). 2009; 84(4):561-564. http://dx.doi.org/10.1002/jctb.2080.

34. Chandradass J and Kim KH. Synthesis and characterization of $\mathrm{CuAl}_{2} \mathrm{O}_{4}$ nanoparticles via a reverse microemulsion method. Journal of Ceramic Processing Research. 2010; 11(2):150-153.
35. Lv W, Luo Z, Yang H, Liu B, Weng W and Liu J. Effect of processing conditions on sonochemical synthesis of nanosized copper aluminate powders. Ultrasonics Sonochemistry. 2010; 17(2):344-351. http://dx.doi.org/10.1016/j.ultsonch.2009.06.006.

36. Fenner LA, Wills AS, Bramwell ST, Dahlberg M and Schiffer P. Zero-point entropy of the spinel spin glasses $\mathrm{CuGa}_{2} \mathrm{O}_{4}$ and $\mathrm{CuAl}_{2} \mathrm{O}_{4}$. Journal of Physics: Conference Series. 2009; 145:012029. http://dx.doi.org/10.1088/1742-6596/145/1/012029.

37. Bayal $N$ and Jeevanandam P. Synthesis of metal aluminate nanoparticles by sol-gel method and studies on their reactivity. Journal of Alloys and Compounds. 2012; 516(5):27-32. http:// dx.doi.org/10.1016/j.jallcom.2011.11.080.

38. Salavati-Niasari M, Davar F and Farhadi M. Synthesis and characterization of spinel-type $\mathrm{CuAl}_{2} \mathrm{O}_{4}$ nanocrystalline by modified sol-gel method. Journal of Sol-Gel Science and Technology. 2009; 51(1):48-52. http://dx.doi.org/10.1007/ s10971-009-1940-3.

39. Yu RS and Yin HH. Structural and optoelectronic properties of p-type semiconductor $\mathrm{CuAlO}_{2}$ thin films. Thin Solid Films. 2012; 526:103-108. http://dx.doi.org/10.1016/j.tsf.2012.11.033.

40. Jarman RH, Bafia J, Gebreslasse T, Ingram BJ and Carter JD. Synthesis of the p-type semiconducting ternary oxide $\mathrm{CuAlO}_{2}$ using the Pechini method. Materials Research Bulletin. 2013; 48(10):3916-3918. http://dx.doi.org/10.1016/j. materresbull.2013.06.003.

41. Tomar N, Ghanti E, Bhagi AK and Nagarajan R. Studies on the hydrolysis of $\left\{\mathrm{Cu}\left[\mathrm{Al}(\mathrm{OPri})_{4}\right]_{2}\right\}$, a single source precursor for $\mathrm{CuAl}_{2} \mathrm{O}_{4}$ spinel. Journal of Non-Crystalline Solids. 2009; 355(52-54):2657-2662. http://dx.doi.org/10.1016/j. jnoncrysol.2009.08.026.

42. Chen Z, Shi E, Li W, Zheng Y and Zhong W. Hydrothermal synthesis and optical property of nano-sized $\mathrm{CoAl}_{2} \mathrm{O}_{4}$ pigment. Materials Letters. 2002; 55(5):281-284. http://dx.doi.org/10.1016/ S0167-577X(02)00378-6.

43. Lu J, Minami KMS, Takami S and Adschiri T. Rapid and continuous synthesis of cobalt aluminate nanoparticles under subcritical hydrothermal conditions with in-situ surface modification. Chemical Engineering Science. 2013; 85:50-54. http://dx.doi.org/10.1016/j.ces.2012.01.061.

44. Ragupathi C, Vijaya JJ, Kennedy LJ and Bououdina M. Combustion synthesis, structure, magnetic and optical properties of cobalt aluminate spinel nanocrystals. Ceramics International. 2014; 40(8):13067-13074. http://dx.doi.org/10.1016/j. ceramint.2014.05.003.

45. Lv W, Qiu Q, Wang F, Wei S, Liu B and Luo Z. Sonochemical synthesis of cobalt aluminate nanoparticles under various preparation parameters. Ultrasonics Sonochemistry. 2010; 17(5):793-801. http://dx.doi.org/10.1016/j.ultsonch.2010.01.018.

46. Wang C, Liu S, Liu L and Bai X. Synthesis of cobalt-aluminate spinels via glycine chelated precursors. Materials Chemistry and Physics. 2006; 96(2-3):361-370. http://dx.doi.org/10.1016/j. matchemphys.2005.07.066.

47. Jafari $\mathrm{M}$ and Hassanzadeh-Tabrizi SA. Preparation of $\mathrm{CoAl}_{2} \mathrm{O}_{4}$ nanoblue pigment via polyacrylamide gel method. Powder Technology. 2014; 266:236-239. http://dx.doi.org/10.1016/j. powtec.2014.06.018.

48. Ouahdi N, Guillemet S, Durand B, Ouatib RE, Rakho LE, Moussa R, et al. Synthesis of $\mathrm{CoAl}_{2} \mathrm{O}_{4}$ by double decomposition reaction between $\mathrm{LiAlO}_{2}$ and molten $\mathrm{KCoCl}_{3}$. Journal of the European Ceramic Society. 2008; 28(10):1987-1994. http:// dx.doi.org/10.1016/j.jeurceramsoc.2007.12.035.

49. Li W, Li J and Guo J. Synthesis and characterization of nanocrystalline $\mathrm{CoAl}_{2} \mathrm{O}_{4}$ spinel powder by low temperature combustion. Journal of the European Ceramic Society. 
2003; 23(13):2289-2295. http://dx.doi.org/10.1016/S09552219(03)00081-5.

50. Mindru I, Marinescu G, Gingasu D, Patron L, Ghica C and Giurginca M. Blue $\mathrm{CoAl}_{2} \mathrm{O}_{4}$ spinel via complexation method. Materials Chemistry and Physics. 2010; 122(2-3):491-497. http://dx.doi.org/10.1016/j.matchemphys.2010.03.032.

51. Tsai WC, Liou YH and Liou YC. Microwave dielectric properties of $\mathrm{MgAl}_{2} \mathrm{O}_{4}-\mathrm{CoAl}_{2} \mathrm{O}_{4}$ spinel compounds prepared by reactionsintering process. Materials Science and Engineering B. 2012; 177(13):1133-1137. http://dx.doi.org/10.1016/j.mseb.2012.05.023.

52. Gama L, Ribeiro MA, Barros BS, Kiminami RHA, Weber IT and Costa ACFM. Synthesis and characterization of the $\mathrm{NiAl}_{2} \mathrm{O}_{4}$, $\mathrm{CoAl}_{2} \mathrm{O}_{4}$ and $\mathrm{ZnAl}_{2} \mathrm{O}_{4}$ spinels by the polymeric precursors method. Journal of Alloys and Compounds. 2009; 483(1):453455. http://dx.doi.org/10.1016/j.jallcom.2008.08.111.

53. Hu G, Deng X, Cao Y and Peng Z. Synthesis of spherical CoAl $\mathrm{O}_{4}$ pigment particles with high reflectivity by polymeric-aerosol pyrolysis. Rare Metals. 2007; 26(3):236-241. http://dx.doi. org/10.1016/S1001-0521(07)60208-3.

54. Xi X, Nie Z, Ma L, Li L, Xu X and Zuo T. Synthesis and characterization of ultrafine $\mathrm{Co}_{2} \mathrm{AlO}_{4}$ pigment by freezedrying. Powder Technology. 2012; 226:114-116. http://dx.doi. org/10.1016/j.powtec.2012.04.029.

55. Yu F, Yang J, Ma J, Du J and Zhou Y. Preparation of nanosized $\mathrm{CoAl}_{2} \mathrm{O}_{4}$ powders by sol-gel and sol-gel-hydrothermal methods. Journal of Alloys and Compounds. 2009; 468(1-2):443-446. http://dx.doi.org/10.1016/j.jallcom.2008.01.018.

56. Kim JH, Son BR, Yoon DH, Hwang KT, Noh HG, Cho WS, et al. Characterization of blue $\mathrm{CoAl}_{2} \mathrm{O}_{4}$ nano-pigment synthesized by ultrasonic hydrothermal method. Ceramics International. 2012; 38(7):5707-5712. http://dx.doi.org/10.1016/j.ceramint.2012.04.015.

57. Cho WS and Kakihana M. Crystallization of ceramic pigment $\mathrm{CoAl}_{2} \mathrm{O}_{4}$ nanocrystals from $\mathrm{Co}-\mathrm{Al}$ metal organic precursor. Journal of Alloys and Compounds. 1999; 287(1-2):87-90. http://dx.doi.org/10.1016/S0925-8388(99)00059-6.

58. Carta G, Casarin M, El Habra NE, Natali M, Rossetto G, Sada $\mathrm{C}$, et al. MOCVD deposition of $\mathrm{CoAl}_{2} \mathrm{O}_{4}$ films. Electrochimica Acta. 2005; 50(23):4592-4599. http://dx.doi.org/10.1016/j. electacta.2004.10.094.

59. Rangappa D, Ohara S, Naka T, Kondo A, Ishii M and Adschiri T. Synthesis and organic modification of $\mathrm{CoAl}_{2} \mathrm{O}_{4}$ nanocrystals under supercritical water conditions. Journal of Materials Chemistry. 2007; 17(41):4426-4429. http://dx.doi.org/10.1039/ b705760a.

60. Nuernberg GDB, Foletto EL, Probst LFD, Campos CEM, Carreño NLV and Moreira MA. A novel synthetic route for magnesium aluminate $\left(\mathrm{MgAl}_{2} \mathrm{O}_{4}\right)$ particles using metal-chitosan complexation method. Chemical Engineering Journal. 2012; 193-194:211-214. http://dx.doi.org/10.1016/j.cej.2012.04.054.

61. Nuernberg GB, Foletto EL, Probst LFD, Carreño NLV and Moreira MA. $\mathrm{MgAl}_{2} \mathrm{O}_{4}$ spinel particles prepared by metalchitosan complexation route and use as catalyst support for direct decomposition of methane. Journal of Molecular Catalysis A Chemical. 2013; 370:22-27. http://dx.doi.org/10.1016/j. molcata.2012.12.007.

62. Stringhini FM, Foletto EL, Sallet D, Bertuol DA, Chiavone-Filho $\mathrm{O}$ and Nascimento CAO. Synthesis of porous zinc aluminate spinel $\left(\mathrm{ZnAl}_{2} \mathrm{O}_{4}\right)$ by metal-chitosan complexation method. Journal of Alloys and Compounds. 2014; 588:305-309. http:// dx.doi.org/10.1016/j.jallcom.2013.11.078.

63. Cullity BD and Stock SR. Elements of X-ray diffraction. $3 \mathrm{rd}$ ed. New Jersey: Prentice-Hall; 2001.
64. Miller GL. Use of dinitrosalisylic acid reagent for determination of reducing sugar. Analytical Chemistry. 1959; 31(3):426-428. http://dx.doi.org/10.1021/ac60147a030.

65. Sing KSW. Reporting physisorption data for gas/solid systems with special reference to the determination of surface area and porosity. Pure and Applied Chemistry. 1982; 54(11):2201-2218. http://dx.doi.org/10.1351/pac198254112201.

66. Fuertes AB, Alvarez D, Rubiera F, Pis JJ, Marbán G and Palacos $\mathrm{JM}$. Surface area and pore size changes during sintering of calcium oxide particles. Chemical Engineering Communications. 1991; 109(1):73-88. http://dx.doi.org/10.1080/00986449108910974.

67. Salem S. Relationship between gel rheology and specific surface area of nano-sized $\mathrm{CoAl}_{2} \mathrm{O}_{4}$ powder manufactured by autoignition technique. Materials Letters. 2015; 139(15):498500. http://dx.doi.org/10.1016/j.matlet.2014.10.118.

68. Chemlal S, Larbot A, Persin M, Sarrazin J, Sghyar M and Rafiq M. Cobalt spinel $\mathrm{CoAl}_{2} \mathrm{O}_{4}$ via sol-gel process: elaboration and surface properties. Materials Research Bulletin. 2000; 35(1415):2515-2523. http://dx.doi.org/10.1016/S0025-5408(00)00444-X.

69. Ahmed IS. A simple route to synthesis and characterization of $\mathrm{CoAl}_{2} \mathrm{O}_{4}$ nanocrystalline via combustion method using egg white (ovalbumine) as a new fuel. Materials Research Bulletin. 2011; 46(12):2548-2553. http://dx.doi.org/10.1016/j. materresbull.2011.08.005.

70. Ragupathi C, Vijaya JJ, Narayanan S, Jesudoss SK and Kennedy LJ. Highly selective oxidation of benzyl alcohol to benzaldehyde with hydrogen peroxide by cobalt aluminate catalysis: a comparison of conventional and microwave methods. Ceramics International. 2014; 41(2):2069-2080. http://dx.doi. org/10.1016/j.ceramint.2014.10.002.

71. Chokkaram S, Srinivasan R, Milburn DR and Davis BH. Conversion of 2-octanol over nickel-alumina, cobalt-alumina, and alumina catalysts. Journal of Molecular Catalysis $A$ Chemical. 1997; 121(2-3):157-169. http://dx.doi.org/10.1016/ S1381-1169(97)00018-6.

72. Salem S, Jazayeri SH, Bondioli F, Allahverdi A, Shirvani $\mathrm{M}$, and Ferrari AM. $\mathrm{CoAl}_{2} \mathrm{O}_{4}$ nano pigment obtained by combustion synthesis. International Journal of Applied Ceramic Technology. 2012; 9(5):968-978. http://dx.doi.org/10.1111/j.17447402.2011.02704.x.

73. Lee GY, Ryu KH, Kim HG and Kim YY. The preparation of blue $\mathrm{CoAl}_{2} \mathrm{O}_{4}$ powders by the malonate method: the effect of the amount of malonic acid used, the formation pathway of $\mathrm{CoAl}_{2} \mathrm{O}_{4}$ crystallites and the characteristics of the prepared powders. Bulletin of the Korean Chemical Society. 2009; 30(2):373-377. http://dx.doi.org/10.5012/bkcs.2009.30.2.373.

74. Alejandre A, Medina F, Salagre P, Fabregat A and Sueiras JE. Characterization and activity of copper and nickel catalysts for the oxidation of phenol aqueous solutions. Applied Catalysis B: Environmental. 1998; 18(3-4):307-315. http://dx.doi.org/10.1016/ S0926-3373(98)00050-2.

75. Ragupathi JJ, Vijaya JJ, Thinesh Kumar R and Kennedy LJ. Selective liquid phase oxidation of benzyl alcohol catalyzed by copper aluminate nanostructures. Journal of Molecular Structure. 2015; 1079:182-188. http://dx.doi.org/10.1016/j. molstruc.2014.09.045.

76. Edrisi M, Tajik S and Soleymani M. Synthesis of $\mathrm{CuAl}_{2} \mathrm{O}_{4}$ nanoparticles by mixed chelates thermolysis and homogeneous precipitation using solubility difference reactions; Taguchi optimization and photocatalytic application. Journal of Materials Science Materials in Electronics. 2013; 24(10):3914-3920. http://dx.doi.org/10.1007/s10854-013-1338-4. 
77. Athar T. Soft chemical approach for the synthesis and characterization of aluminium copper oxide $\left(\mathrm{CuAl}_{2} \mathrm{O}_{4}\right)$ nanopowder. Advanced Materials Letters. 2015; 6(3):265-270.

78. Hu CY, Shih K and Leckie JO. Formation of copper aluminate spinel and cuprous aluminate delafossite to thermally stabilize simulated copper-laden sludge. Journal of Hazardous Materials. 2010; 181(1-3):399-404. http://dx.doi.org/10.1016/j. jhazmat.2010.05.024.

79. Almeida RN, Santos SF, Sampaio JA, Luz AB, Ogasawara T and Andrade MC. Synthesis of ceramic pigments by chemical precipitation. Cerâmica. 2007; 53(325):57-61. http://dx.doi. org/10.1590/S0366-69132007000100008.

80. Dohnalová Ž, Šulcová P and Trojan M. Colour possibilities of the CuAl2-xLnxO4 pigments. Materiafy Ceramiczne/Ceramic Materials. 2008; 60(4):139-142. Available from: <http://www. ptcer.pl/mccm/en/article-details/60/4/18>. Access in: 10/07/2015.
81. Marques CH, Mesquita A, Araújo VD and Bernardi MIB. Influence of the $\mathrm{pH}$ on $\mathrm{Al}_{2} \mathrm{O}_{3}: \mathrm{CuO}$. Pigments prepared by a polymeric precursor method. Materials Research. 2013; 16(1):100-104. http://dx.doi.org/10.1590/S1516-14392012005000150.

82. Gaspari JW, Gomes LH and Tavares FCA. Imobilização da inulinase de Kluyveromyces marxianus para a hidrólise de extratos de Helianthus tuberosus L. Scientia Agricola. 1999; 56(4):11351140. http://dx.doi.org/10.1590/S0103-90161999000500015.

83. Kovaleva TA, Holyavka MG and Bogdanova SS. Inulinase immobilization on macroporous anion-exchange resins by different methods. Bulletin of Experimental Biology and Medicine. 2009; 148(1):39-41. http://dx.doi.org/10.1007/s10517-009-0623-y.

84. Karimi M, Habibi-Rezaei M, Safari M, Moosavi-Movahedi AA, Sayyah M, Sadeghi R, et al. Immobilization of endo-inulinase on poly-D-lysine coated CaCO3 micro-particles. Food Research International. 2014; 66:485-492. http://dx.doi.org/10.1016/j. foodres.2014.08.041. 